\title{
Demokrasi dan Sisi Gelapnya: Pengalaman dari Eropa, Afrika, Asia dan Amerika Latin
}

\section{Daniel Hutagalung}

Aktivis pergerakan, alumnus UI dan Universitas Birmingham UK

\section{Abstract}

Article explains that there is a view that democracy and violence often go hand in hand, and the point at which democratic states decide to use violence is merely subjective, and is a matter of political decision, and not ethical necessity. This is indeed a difficult thing to accept in the context of democracy, even though it is more representative of a realistic calculation or consideration that encourages politicians or the government in deciding whether or not to use violence. Indonesia's future seems full of uncertainty, because liberal and socialist influence continues to diminish, while secularism continues to be battered by the rise of political Islamization. This is especially true if the country weakens and a number of political factions carry out radicalization.
Keywords

democracy, gelap, kekerasan; Eropa

Timur, Asia; Amerika Latin; Afrika

\section{Pendahuluan}

Dalam upaya perwujudannya di abad duapuluh, demokrasi selalu mendapatkan tantangan yang serius. Mulai dari perang dunia, holocaust, rasisme, pembantaian etnis (genocide) di Afrika dan wilayah Balkan, sampai berbagai kekerasan komunal, termasuk di Indonesia. Konflik dan kekerasan menjadi wajah kelam upaya membangun demokrasi. Jika konflik dan kekerasan menjadi aspek intrinsik dari politik demokratik, maka berbagai manisfestasi dari konflik harus menjadi subyek analisa kritis untuk dievaluasi sejauh mana manifestasi tersebut menyandarkan dirinya pada kekerasan. Studi Michael Mann The Dark Side of Democracy, mencoba untuk menganalisa mengapa di alam demokrasi banyak terjadi pembantaian etnis, sebagaimana terjadi di Armenia, Holocaust Nazi, Kamboja, Yugoslavia, Rwanda, dan sejumlah kekerasan yang terjadi di Eropa, India dan Indonesia. Mann menggunakan istilah "murderous cleansing" atau pembunuhan dengan tujuan pembersihan, yang sifatnya modern yang merupakan sisi gelap demokrasi.[1] Tesis utama Mann adalah murderous cleansing merupakan hasil dari kegagalan sekaligus kebingungan demos (demokrasi) memahami ethnos (kelompok etnis).[2] Mann menguraikan sisi gelap demokrasi semenjak aspirasi demokrasi muncul di Eropa, namun juga pada saat yang sama terjadi kolonialisasi negara-negara Eropa terhadap negara-negara di Asia, Afrika dan Amerika Selatan. 


\section{Kajian Pustaka}

\section{Demokrasi, Kekerasan Etnis dan Murderous Cleansing}

Demokrasi umumnya dipahami sebagai pemerintahan rakyat, dan selalu dibayangkan sebagai sebuah sistem yang mengelola politik dengan cara non-kekerasan. Konsep tersebut menempatkan ide mengenai kesetaraan politik dan keadilan sebagai fondasi bagi institusi dan prosedur politik yang mendapatkan dukungan dari rakyat. Kemudian, penataan prosedur demokrasi dirancang dengan tujuan untuk melindungi orang-orang maupun negara dari penggunaaan kekerasan sebagai cara untuk berkompetisi. Namun sebagaimana dicatat Michael Mann, banyak demokrasi yang terinstitusionalisasi dan stabil dalam sejarah justru menujukkan standar moral yang rendah, sebagaimana diungkapkan Mann:

Most of them committed sufficient ethnic cleansing to produce an essentially monoethnic citizen body in the present. In their past, cleansing and democratization proceeded hand in hand. Liberal democracies were built on top of ethnic cleansing, though outside of the colonies this took the form of institutionalized coercion, not mass murder.[3]

Dari sini, Mann memulai analisanya dengan melihat gejala pembentukan identitas keKita-an, atau "We, the people", dalam dua versi, yakni versi liberal dan versi organik. Versi liberal adalah yang disebutkan dalam pembukaan konstitusi Amerika Serikat dan sudah menjadi istilah yang sarat legitimasi di banyak negara modern, dan secara utuh dipahami sebagai kolektivitas moral dan kebaikan. Namun jika dua makna dari "the people", yakni demos dan ethos digabungkan, muncul persoalan terhadap kelompok etnis lain yang hidup dalam wilayah yang sama.[4] Warga yang merasa memiliki keistimewaan akan melibatkan unsur diskriminasi terhadap etnis yang berasal dari luar. Pada titik yang paling ekstrim, kelompok yang berasal dari luar akan diasingkan dan dibersihkan dari wilayah "the people".

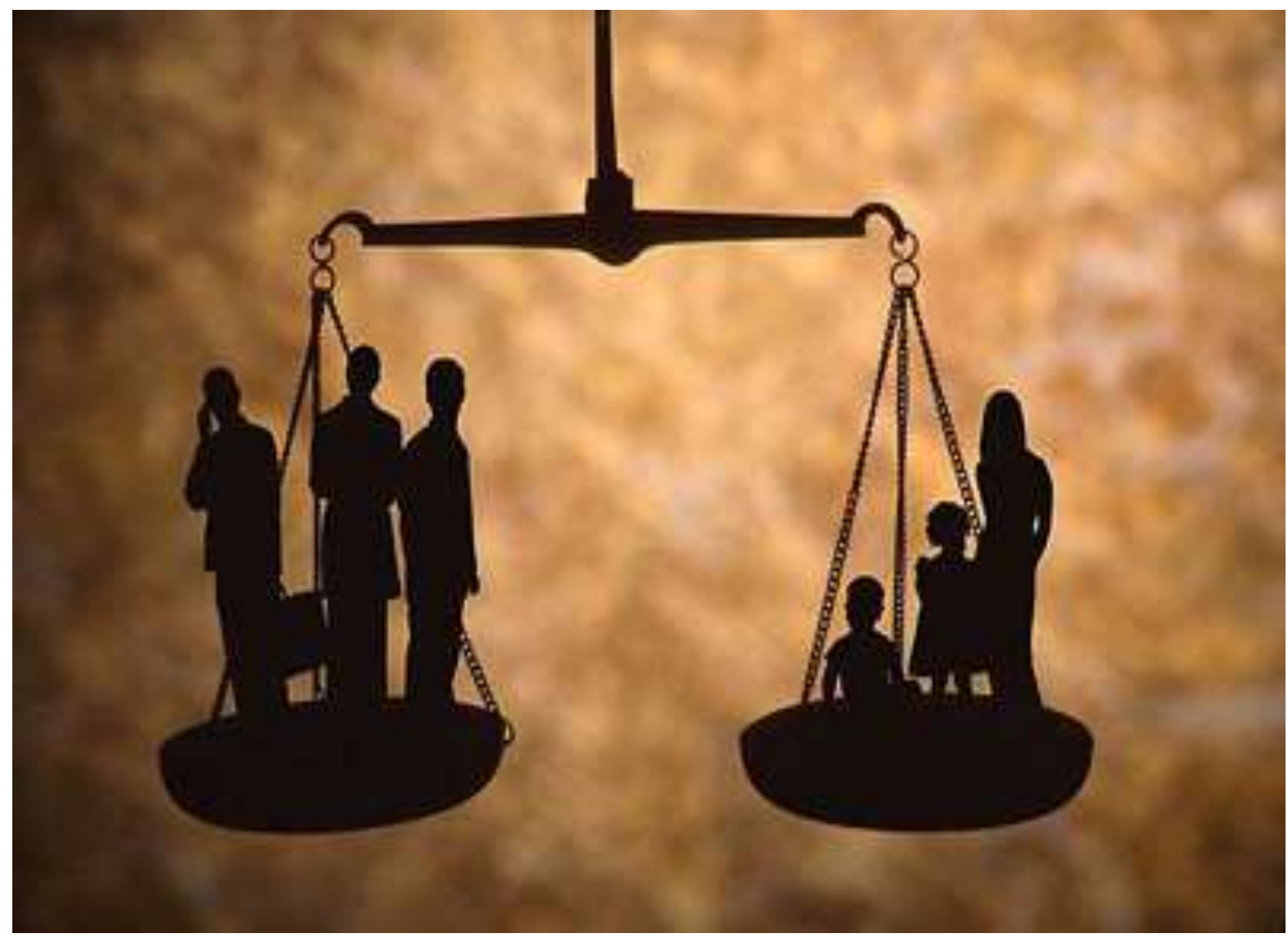


Versi organik dirujuk Mann pada gagasan yang muncul di Austria, yang mendefiniskan "people" sebagai "one and indivisible, united, integral".[5] Ide ini kemudian diserap oleh Tiso, seorang pimpinan nasionalis Slowakia, yang mendefiniskan sebuah bangsa sebagai "a community of people who are of single origin, single physical type, single character, single language, single set of customs and single culture of equal goals, and they constitute an organic whole in a coherent territory".[6] Versi organik ini yang kemudian mengarah pada model nasionalisme yang meyakini (1) karakter, semangat, jiwa nasional yang sifatnya abadi dan dapat dibedakan dari bangsa lain; (2) hak mereka terhadap negara yang dapat mengekpresikan karakter, semangat dan jiwa nasional tersebut secara utuh; (3) hak mereka untuk menyingkirkan kelompok-luar (out-groups) yang karakternya berbeda, dan hanya akan memperlemah bangsa. Mann menguraikan bahwa bangsa-bangsa yang sekarang dikenal sebagai negara demokratis, mendirikan demokrasinya di atas pembantaian era kolonialiasi atau pendudukan, sebagaimana dilakukan Spanyol di Meksiko, orang kulit putih terhadap Aborigin di Australia, pembantaian suku asli Indian oleh kulit putih si AS, pembantaian oleh kolonial Russia di Caucasus dan kolonialisme Jerman di Afrika Barat-Daya (sekarang Namibia).

\section{Pembahasan}

Pembersihan oleh kolonial (colonial cleansing) merupakan salah satu cikal-bakal terjadinya berbagai pembersihan etnis sampai abad duapuluh. Colonial cleansing merupakan bentuk pembersihan etnis yang terjadi di jaman modern, jaman di mana demokrasi mulai bersemi dan berkembang. Menurut Mann, seluruh koloni Eropa diduduki lewat kekerasan, tetapi hanya di sebagian koloni yang terjadi murderous cleansing. Dalam melihat hubungannya dengan demokrasi, Mann menyatakan bahwa "I argue that the more they embodied settler democracy, either de facto or de jure, the more the murderous cleansing".[7] Jadi, semakin terbentuk demokrasi di kalangan settler,[8] maka semakin banyak terjadi pembantaian. Mann menjelaskan bahwa ada faktor-faktor yang membedakan dan mempengaruhi tingkat pembantaian, seperti jenis ekonomi atau tipe penguasaan atas penduduk asli.

Faktor pertama adalah kekuatan ekonomi di mana konflik umumnya terjadi dalam bentuk konflik ekonomi secara langsung mengenai siapa yang seharusnya memiliki dan menggunakan tanah, antara kaum kolonial dengan penduduk asli. Konflik ini terjadi di sektor perdagangan, yang kemudian mengarah pada pendudukan; terjadinya perampasan dan permintaan upeti; para pendatang menggunakan buruh yang tersebar luas dan pengambilan tanah secara paksa; penggunaan buruh yang terkonsentrasi dengan perlakuan yang brutal dan tidak manusiawi; para pendatang tidak menggunakan penduduk asli sebagai buruh; Faktor kedua adalah kekuatan politik, yang membawa berbagai macam bentuk perlakuan terhadap penduduk asli. Umumnya pemerintah kolonial hampir tidak pernah menginginkan pembunuhan terhadap penduduk asli, namun kerap konflik dengan para pendatang mendorong para pendatang untuk menghilangkan populasi penduduk asli, yang menempatkan pemerintah kolonial berada dalam posisi dilemma. Apa yang terjadi di AS antara pendatang dengan penduduk asli Indian, menurut Mann adalah faktor kekuatan politik, di mana kemudian para pimpinan suku, sekalipun memiliki otonomi, namun dilemahkan kekuatan politiknya; Faktor ketiga adalah kekuatan militer, di mana kekuatan militer digunakan untuk menuduki suatu wilayah koloni; Faktor keempat adalah ideologis, yakni penyebaran agama; Faktor kelima adalah biologi/ekologi, yakni orang Eropa membawa penyakit yang penduduk asli tidak memiliki kekebalan terhadapnya, sehingga banyak yang mati oleh penyakit bawaan dari Eropa. 
Dari uraiannya tersebut, Mann menarik kesimpulan bahwa colonial cleansing sesungguhnya mewakili apa yang yang ia sebut sisi gelap pertama dari demokrasi modern yang sedang bersemi, yakni di mana para pendatang (settlers) menikmati situasi memerintah diri-sendiri (self-rule) secara de facto, yang dalam realitas lokal merupakan rejim paling demokratis di dunia pada saat itu. Pembantaian yang dilakukan oleh para pendatang umumnya lebih buruk dari yang dilakukan oleh penguasa imperium seperti Spanyol, Portugis, Inggris melalui para gubernur atau penguasa lokal yang menjadi perwakilan imperium.[9] Misalnya di California, pembunuhan sacara musyawarah terjadi setelah kerajaan Spanyolmenyerahkan tampuk kekuasaan pada para pendatang. Demikian juga dengan kebanyakan bangsa Indian yang lebih mendukung negara kolonial Inggris, dan bukan mendukung revolusi para pendatang dalam perang kemerdekaan.

Pada era abad duapuluh, pada saat demokrasi menjadi suatu gejala yang mondial, dan menjadi cita-cita banyak bangsa, termasuk bangsa-bangsa yang dijajah, lahir manifestasi dari ide mengenai ke-Kita-an yang didasarkan pada keunggulan satu bangsa dari bangsa lainnya, dan berujung pada pembantaian Yahudi oleh Nazi. Pada akhir abad duapuluh menginjak abad duapuluhsatu, hal hampir serupa berlangsung di Rwanda, Somalia, Sudan dan bangsa-bangsa pecahan Yugoslavia seperti Serbia dan Bosnia. Pembersihan etnis menjadi gejala yang menghebohkan di ruang demokrasi. Dan menjadi suatu pertanyaan besar: apakah demokrasi bisa digunakan untuk tindakan anti-demokrasi? Pembersihan etnis Bosnia dan Albania oleh Serbia dilandaskan pada semangat membangun bangsa dengan membersihkan para pengkhianat di dalam negeri lewat constitutive violence atau kekerasan yang dilegalkan, oleh Milosevic dengan menggunakan retorika musuh internal yang dulu pernah dilakukan Tito. Dalam artikelnya, Glenn Bowman, melihat bahwa apa yang dilakukan Milosevic adalah,

[...] used Tito own rhetoric of "internal enemies" to create a domain of "Serbian interests" for which he could speak... Milosevic turned the Titoist rhetoric of internal enemies to nationalist use by suggesting that Albanians "inside" Serbia would make it impossible for Serbian individuals to live as Serbs on Serbian ground.[10]

Mann secara khusus juga melihat persoalan kekerasan dan pembunuhan etnis yang terjadi di Indonesia. Mann, melihat rangkaian kekerasan di Indonesia dilandaskan pada persoalan etnisitas, ras dan agama, yang memang merupakan negara multietnis. Sejumlah hal yang dilhat Mann adalah, institusionalisasi negara yang lemah, sehingga selalu ada ketagangan antara kaum nasionalis dengan Islam, juga dengan kalangan militer (Mann 2005: 491). Indonesia juga tidak mampu melakukan kontrol terhadap kapitalisme, di mana $70 \%$ aktivitas ekonomi dikontrol secara rasial oleh warga keturunan Tionghoa yang hanya berjumlah $4 \%$ dan tidak memiliki kedaulatan politik. Ini juga selalu melahirkan ketegangan. Jadi dari seluruh wilayah pinggiran, upaya untuk menciptakan bangsa Indonesia seperti Jawa (yang dilihat sebagai imperialis asing) lewat asimilasi ideologis, eksploitasi dan eksklusi ekonomi, dan tekanan politik dan militer. Politiknya adalah membagi dan memerintah wilayah lokal. Namun ini semua membawa kepada persoalan kekerasan etnis maupun invasi yang dilakuan oleh Indonesia.

Contoh yang dikemukakan Mann adalah pembantaian anggota partai komunis yang disusul dengan kekerasan yang tak lazim dan militerisme yang dijalankan oleh rezim Soeharto, serta pembentukan Orde Baru di bawah Soeharto yang banyak dipengaruhi unsur kebudayaan Jawa. Demikian juga dengan pendudukan Timor-Timur, yang bukan merupakan bagian dari Indonesia - yang merupakan koloni Portugis dan bukan koloni Belanda - sampai pendudukan di tahun 1975, yang kemudian lepas dari Indonesia lewat referendum pada tahun 1999.

Kasus lain yang dilihat Mann adalah Aceh, di mana dianggap merupakan wilayah yang rentan terhadap kekerasan etnis, karena Aceh memgang nilai dan tradisi lama yang 
melakukan klaim atas kedaulatan wilayahnya, di mana Hasan Tiro, pimpinan perlawanan Aceh, menyatakan bahwa Indonesia merupakan kolonialis Jawa yang menggantikan penjajah belanda untuk menduduki Aceh. Untuk menghadapi persoalan Aceh, pemerintah Indonesia yang demokratis setelah reformasi 1999, justru mengambil jalan kekerasan etnis, yakni mengirimkan tentara dan memberlakukan keadaan darurat perang. Hal yang sama juga terjadi terhadap wilayah Papua, di mana sekitar satu juta warganya adalah tak memiliki negara (stateless), dan hidup di wilayah-wilayah kepulauan di sekitar Papua Nugini, karena adanya konflik antara kelompok nasionalis pembebasan Papua dengan pemerintah Indonesia.

Bentuk kekerasan lain yang disorot Mann adalah kekerasan etnis antar warga, sebagaimana terjadi di Maluku, Kalimantan dan Poso, dan kerusuhan rasial anti-Tioghoa pada 1998. Inilah yang juga menjadi dilema dalam demokrasi, di mana eskalasi kekerasan etnis justru mengemuka dan meluas di era yang lebih demokratis.

Mann melihat bahwa institusi demokrasi yang stabil belum terbentuk di Indonesia. Bahaya akan muncul jika rezim melemah, dan faksi-faksi yang memainkan kartu adalah nasionalis-integralis dan nasionalis-religius.[11] Jadi hubungan pusat dengan daerah mendorong terjadinya kontestasi kedaulatan. Murderous cleansing tidak berlangsung pada saat tidak terjadi persaingan kedaulatan, atau pada saat institusi negara yang stabil hadir dan tidak ada krisis ekonomi dan politik secara internal, atau krisis geopolitik yang eksternal. Menurut Mann, masa depan Indonesia kelihatannya penuh ketidakpastian, karena pengaruh liberal dan sosialis terus berkurang, sementara sekulerisme terus digempur oleh bangkitnya Islamisasi politik. Ini terutama jika negara melemah dan sejumlah faksi politik melakukan radikalisasi.

Contoh terkini lain sebagaimana yang dilihat oleh Slavoj Zizek adalah menguatnya politik anti-imigran di Prancis, Jerman, Austria dan Belanda yang merupakan semangat kebanggaan baru atas identitas kultural dan historis, di mana penduduk asli menemukan alasan berpijak untuk menekankan bahwa para imigran adalah tamu yang harus mengakomodasi diri mereka terhadap nilai-nilai budaya yang didefinisikan oleh masyarakat yang menjadi tuan rumah, dengan semboyan: "it is our country, love it or leave it".[12]

\section{Mendamaikan Demokrasi dan Kekerasan}

Dalam studi John Keane, banyak kasus yang tercatat bahwa pemerintah demokratis justru melakukan kekerasan terhadap sebagian warganya. Kekerasan jenis itu disebut penegakan hukum dan aturan (law and order), perlindungan bagi kepentingan publik, menjaga keamanan, atau melawan terorisme. Bagi Keane, di masyarakat sipil yang memiliki afinitas kuat atas demokrasi terdapat istilah baru untuk menjelaskan kekerasan, yakni "democratise" violence atau kekerasan yang demokratis.[13] Artinya kekerasan dalam demokrasi menjadi "demokratis" pada saat ia dilekatkan pada penanda seperti penegakan hukum dan aturan. Ini bukan semata-mata suatu bentuk kekerasan yang diinstitusikan, namun juga sekaligus dilegalkan.

Sampai pada titik ini maka argumen yang pantas dipertanyakan adalah: apakah pandangan ortodoks mengenai demokrasi sebagai antidote dari kekerasan bukan sesuatu yang menyesatkan, dan lebih buruk lagi, berpotensi lalai dalam hal bagaimana sistem demokrasi bergantung pada kekerasan untuk tetap berkuasa dan menyingkirkan orang-orang yang mencoba untuk menantang dan meremehkan tatanan dominan.

Dari pertanyaan tersebut bisa merujuk pada argumen kritis yang melihat kekerasan sebagai sesuatu yang bersifat alami atau kodrati. Artinya pada saat harus mempertimbangkan perilaku masyarakat di alam demokrasi, khususnya demokrasi liberal, yang kadangkala melakukan tindakan kekerasan, maka pembenarannya dipijakkan pada justifikasi hukum kodrati. Maksudnya, kekerasan oleh demokrasi bisa dibenarkan sejauh dilakukan untuk 
melindungi demokrasi jika demokrasi mengalami ancaman.[14] Dalam hal ini justifikasi tersebut, misalnya diberlakukan untuk kasus "perang melawan terorisme".

Argumen lain yang juga bisa dirujuk adalah Chantal Mouffe, yang melihat bahwa di dalam demokrasi inheren adanya hubungan antagonistik, yakni kawan/lawan yang membentuk hubungan "kita" dan "mereka" (us/them). Bagi Mouffe, perjuangan demokratik merupakan ujud dari "collective will" dan identitas kolektif, di mana "kita" hanya bisa terbentuk dengan menciptakan lawan atau "mereka",[15] namun Mouffe menekankan bahwa relasi ini tetap dalam konteks politik pluralis.[16]

\section{Kesimpulan}

Dengan merujuk pada sejumlah argumen setidaknya ada jawaban terhadap kecemasan Mann, meskipun jawaban tersebut mensyaratkan sejumlah hal, yakni penerimaan terhadap pluralitas sebagai syarat penting demokrasi, baik secara substansi maupun prosedurnya. Ada pandangan bahwa demokrasi dan kekerasan kerap berjalan beriringan, dan poin di mana pada negara demokratis memutuskan untuk menggunakan kekerasan, itu semata-mata bersifat subyektif, dan merupakan persoalan keputusan politik, dan bukan keharusan etis. Ini memang suatu hal yang sulit untuk diterima dalam konteks demokrasi, meskipun demikian itu lebih mewakili suatu perhitungan atau pertimbangan realistis yang mendorong politisi atau pemerintah dalam memutuskan berindak atau tidak dalam penggunaan kekerasan.

\section{Daftar Pustaka}

Michael Mann, The Dark Side of Democracy: Explaining Ethnic Cleansing (Cambridge: Cambridge University Press, 2005), hal. 2.

Glenn Bowman, "Constitutive Violence and the Nationalist Imaginary: The Making of "The People' in Palestine and 'Former Yugoslavia'", dalam Fransisco Panizza (Ed.), Populism and the Mirror of Democracy (London: Verso, 2005), hal. 135.

Michael Mann, op. cit., hal 497.

Slavoj Zizek, Violence: Six Sideways Reflections (New York: Picador, 2008), hal. 41.

Adrian Little, Democratic Piety: Complexity, Conflict and Violence (Edinburgh: Edinburgh University Press, 2008), hal. 123.

Chantal Mouffe, On The Political (London: Routledge, 2005), hal. 15.

Bowman, Glenn, "Constitutive Violence and the Nationalist Imaginary: The Making of 'The People' in Palestine and 'Former Yugoslavia', dalam Fransisco Panizza (Ed), Populism and the Mirror of Democracy (London: Verso, 2005).

Keane, John, Violence and Democracy (Cambridge: Cambridge University Press, 2004).

Little, Adrian, Democratic Piety: Complexity, Conflict and Violence (Edinburgh: Edinburgh University Press, 2008).

Mann, Michael, The Dark Side of Democracy: Explaining Ethnic Cleansing (Cambridge: Cambridge University Press, 2005).

Mouffe, Chantal, On The Political (London: Routledge, 2005).

Zizek, Slavoj, Violence: Six Sideways Reflections (New York: Picador, 2008). 